\title{
Development of Entrepeneurship Training Based on Life Skill for Islamic Boarding School Students
}

\author{
Siti Afifatus Saidah, Sri Handajani \\ Home Economics Department \\ Universitas Negeri Surabaya \\ Surabaya, Indonesia \\ srihandajani@unesa.ac.id
}

\begin{abstract}
Education in boarding schools aims to realize a religious generation that is self-reliant and beneficial to society. One of them seeks entrepreneurship skills through training with appropriate training tools. The purpose of this study was to describe the feasibility of life skill based entrepreneurship training tools and to describe the implementation and the training results. This training tool development research refers to the Plomp model. The subject of this research were the students of Darul Falah V Boarding School Cukir Jombang who were interested in entrepreneurship. The research instrument were an interview guide, a questionnaire, a check list, a validation sheet, a test sheet, and a training implementation sheet. Data collection techniques were interviews, questionnaires, documentation, device reviews, and assignments. Data analysis techniques included analysis of device validation results. The results of life skill entrepreneurship training tools such as syllabus, power point, and module by experts have fulfilled the valid categories so that the device was suitable for use. The results showed that the percentage of training was $92 \%$ with very good category. The result of appraisal of affective aspect of entrepreneurship training participants on average was 86,7 with very good category. The results of the cognitive aspect assessment of 83 participants with excellent category. The result of psychomotor assessment of participants was 90.2 with very good category.
\end{abstract}

Keywords - training, entrepreneurship, life skill

\section{INTRODUCTION}

Boarding schools hopes to realize an independent generation that is beneficial to society both in religious and general sciences. This is in accordance with the purpose of the Islamic boarding school that is to create students who have a faithful personality and are devoted to God, with noble values beneficial to society by being able to stand alone. In accordance with [1], the most important thing is to create favorable conditions for increasing business activity in the wider segment of society, especially for young people, the creation of small business subjects and new workplaces in this field. Islamic boarding school does not want its alumni to be unemployed. This will be a burden for boarding schools and for the community. However, in reality the students have not been able to live independently because they have not maximized the potential they have and the Islamic boarding school has not provided work supplies. One solution is to provide entrepreneurship training based on life skill. Training interventions considered very important, and barriers related to financial resources, experience, time, infrastructure, and not risk aversion [2]. In this case the transition to a new system that will enable it to change quickly if utilizing technology and content education and to motivate students not only for research, but also for business activities [3].

Educational institutions must graduate students capable for intellectual business, possess new knowledge and motivating skills graduates to achieve success in conditions of constantly changing market conditions [4]. Therefore, educational institutions or Islamic boarding schools must train their students not only to produce new knowledge, but also for innovation, ready to work in conditions of uncertainty, namely by the presence of entrepreneurship training. Some researchers have found that entrepreneurship education has a positive impact on the perception of elements, such as self-efficacy [1]. There is a belief that entrepreneurship training has a positive effect on students' awareness of entrepreneurial care and the recognition of the reality of creating their own business [5]. Some authors have acknowledged entrepreneurial contributions to the creation of mini companies that prioritize social benefits to the economy and use their surplus resources to provide higher employment and income for disadvantaged groups (Drucker) cited in El Brashi [6-9]. Interest for training in business began to develop since the late 1950s early 1960s when McClelland's work (The Achieving Society, 1961) and F. Collins, G. Moore and B. Unwalla monograph-The Enterprising Man (1964) were the first time published [10].

Entrepreneurship training works well when using the device. The purpose of this study was to describe the feasibility of life skills based on entrepreneurship training devices, describing the implementation of training and describing the results of entrepreneurship training using developed tools. Life Skill is a skill that must be possessed by a person to dare to face life and life problems without feeling depressed, then proactively and creatively seek and find solutions to overcome them [13]. Life skill training is an education that provides basic supplies and exercises that are carried out correctly to participants about the values of life that are needed and useful for the development of the life of the participants. Entrepreneurship training is expected to be able to bring participants to face life's challenges so they can live independently. Askun and Yildirim, Simon, and Thurik and Wennekers [12-14], argue that entrepreneurship is a type of behavior that centers on economic opportunities and resources; In addition, it is a combination of risk, creativity, personal success, and innovation. Entrepreneurship must adopt financial, moral, and social responsibility to build new and profitable business ideas that can contribute to solving social problems. 
According to Suhadi [15] learning tools are a number of tools, materials, media, instructions, and guidelines to be used in the learning process. Training tool is a tool or completeness used for training can be syllabus, power point, and module. Syllabus is developed because syllabus is a learning plan developed based on Graduate Competency Standards as a reference for the preparation of learning framework. This is according to the opinion of Sanjaya [16] ie syllabus developed based on Graduate Competency Standards. Power point one of the media in training. Device is any tool that can be used as a message channel to achieve the purpose of teaching [17]. Power point developed because according to opinion Sanjaya [16] power point not only as a tool for learning, but as a source of learning. Modules are developed because according to Amri [18] module is a learning resource designed for self-learning system. Through the entrepreneurship training module developed the participants are expected to learn and do entrepreneurship independently. The development of training tools used refers to the model introduced by Plomp. There are five stages in developing the learning model that is initial investigation, design, realization or construction, test, evaluation, and revision, and implementation.

The result of the training is the ability of the learners after receiving information from the training process [19]. Benjamin, Bloom, et al classified learning and training outcomes into three categories, namely cognitive, affective, and psychomotor. Affective assessment in this study is used to determine the entrepreneurship spirit of the participants, cognitive assessment is used to determine the ability to make business plans, and psychomotor assessment is used to determine the ability of entrepreneurship.

\section{METHOD}

This research includes research development (Research and Development) because researchers want to develop entrepreneurship training devices. This development research refers to the Plomp model. The training tool development stage was not up to the implementation stage but up to the test, revision and evaluation stage. Implementation stage was related to the implementation of final prototype on a wider scope. The development of training tools in this research was carried out only until the final prototype was ready to be implemented on a wider scope. This was based on consideration of time limitations of research, requiring many training participants, requiring several different research sites. Therefore, this research was not until the implementation phase but only until the field trial stage was an attempt to conduct evaluation and revision until a final prototype was obtained which is ready to be implemented on a wider scope. The subject of the study were Darul Falah V students has an entrepreneurial interest of 20 people. Training was given to students who were interested in business because according to Sanjaya [16] students can learn anything according to interests and learning styles. The development stage of the training device that was done with the Plomp model there are several phases. The initial investigative phase collects information on the problems and needs that exist in the boarding school. Design phase designing training device as needed. Phase of relation or construction that is realizing the results of training device design. Test phase, evaluation, and revision was to validate by experts and test the device. The research instrument was the interview guide to obtain the data that is information about the problems and the needs contained in the boarding school. Questionnaire to determine the number of students who attended the training and to know the entrepreneurship spirit of the students after attending entrepreneurship training using the device, Checklist to check the information needed in research on boarding school. A validation sheet to provide an assessment by an expert or expert on the developed learning device [20]. Test sheets for measuring cognitive and psychomotor abilities. The training implementation sheet to measure the implementation of entrepreneurship training. Data collection techniques are interviews, questionnaires, documentation, device reviews, and assignments. Data analysis techniques included analysis of the device validation results by finding the average score then described with range 1 to 4 (not feasible, less feasible, feasible enough, feasible).

\section{RESUlt AND DISCUSSION}

Phase of Investigation The activities undertaken at this stage was to collect information on the problems and needs contained in the boarding school. Based on the results of interviews to the cleric teachers obtained information that the majority of graduates boarding school woman can not live independently because it was still dependent on the family. One reason was that student have not maximized their potential. It was therefore necessary to create independent santri activities, not dependent on the family. Design Phase The activities undertaken were designing tools developed according to the needs of the problems contained in the boarding school. The tools developed were entrepreneurship training tools including the preparation of syllabi, power point, and modules. The basic competencies in the developed syllabus were to build a life skills based entrepreneurship skill, understand the steps to start entrepreneurship, create a business plan, undertake entrepreneurship training, and do entrepreneurship. The contents of power points and modules are made referring to the syllabus that has been compiled. Phase Realization This stage as the realization of the results of designing training tools. Covers the design of syllabus, embodies the module design based on the syllabus, determines the instructional media and manifests the power point design to obtain the data that is information about the problems and needs contained in the boarding school, develop training syntax by making the RPP (Training Implementation Plan). The results of device development are researched whether they were ready to be tested by experts. Test Phase, Evaluation, and Revision This stage was carried out two main activities, namely validation activities and field test results validation. Validation to determine the feasibility of the device while field trials to determine the implementation of training and training results using the tools developed.

Validation was done by experts by way of analysis of the developed device that is syllabus, power point, and module. Entrepreneurship training devices are reviewed by experts who were considered as educational and training specialists. The results of the study by the validator on the developed syllabus obtained an average score of 3.81 with valid criteria.

The findings of this study clearly showed Therefore the developed syllabus is feasible for use in the field. The appraisal includes the content presented, the language, and the time. The syllabus shows that it wais developed based on the competency standards of graduates in accordance with 
the opinion of Sanjaya [16] ie syllabus developed based on the Graduate Competency Standards . The result of the study by the validator to the power point developed obtained an average score of 3.88 with valid criteria. Therefore the developed power point is feasible for use in the field. The appraisal includes language, drawing and power point design, as well as material content. The developed power point aims as a tool for conveying information related to the training materials. The goal was in the opinion of Djamarah $\&$ Zain [21] power point was any tool that can be used as a message channel to achieve the purpose of teaching. The developed module aims as a learning resource independently. Based on the results of the feasibility assessment module, developed modules are valid and feasible with a score of 3.89. The eligible shows that the developed aspect is arranged systematically, referring to clear training objectives, so that it can be studied by the participants independently. This was in the opinion of Amri [18] module was a learning resource for the whole learning program, arranged systematically, referring to clear learning objectives, so that learners can learn independently.

TABLE I. RECAP RESUlt OF OBSERVATION OF ENTREPRENEURSHIP TRAINING CONDUCT

\begin{tabular}{|c|c|c|}
\hline Meeting & Percentage (\%) & Categories \\
\hline 1 & 90 & Very Good \\
\hline 2 & 83 & Very Good \\
\hline 3 & 94 & Very Good \\
\hline 4 & 100 & Very Good \\
\hline Average & 92 & Very Good \\
\hline
\end{tabular}

Aspects developed in the module include the structure of the sentence module, the organization of sentence writing, and the language used. This aspect consists of a general arrangement of presentation, a general appearance of interest, and a consistent linkage between the subject matter. Appropriate assessment of all aspects assessed indicates that the module developed already has module characteristics. According to Sanjaya [16] module characteristics include a whole and systematic learning program, containing goals, materials or activities and evaluation, presented communicatively, and designed for self-learning system.

Observation of the implementation of entrepreneurship training conducted by teachers and custodian of cottage. Based on Table 1 showed that entrepreneurship training for four basic competency meetings is $92 \%$ in very good category. The basic competence of the first meeting was to build entrepreneurial spirit based life skills and understand the steps to start entrepreneurship. The basic competence of the second meeting was to make a business plan. The third basic competence is to conduct training to create entrepreneurial products. The fourth competency was the participant doing the entrepreneurial application. The fourth meeting was the application of entrepreneurship according to its potential and make a sales report of the business undertaken. The efforts of the participants do not have to match the skills given in the training of making meatballs and nuggets. This was because entrepreneurship training aims so that participants can entrepreneurship according to their potential (life skills). Training to make meatballs and nuggets given as one example of culinary business that many consumers demand. The basic competencies of the four meetings are several indicators, but there were some unfulfilled indicators. The indicator was no demonstration of making risoles and giving the task of feasibility study. Implementation was due to limited time available while training takes a lot of time to get maximum results. Performance appraisals used to determine the outcome of training activities during trials of entrepreneurship training devices. The test of the device conducted by the training to the participants who are interested in entrepreneurship. The training participants were selected based on the entrepreneurship interest of the santri. This was done to facilitate the achievement of the goal of entrepreneurship training. Based on the assessment of interest from 70 students there were 20 santri who have good entrepreneur interest. The success of santri attending the training was seen from the result of affective, cognitive and psychomotor assessment. Affective assessment was done at the first meeting is the assessment of entrepreneurship. Cognitive assessment was done at the third meeting was a test determine the selling price and create a business plan. Psychomotor assessment conducted at the last meeting is the fourth meeting was the assessment of business results in the form of sales reports. The affective aspect assessed to know the entrepreneurial spirit by way of participants in the questionnaire. Cognitive aspect assessed to know the ability to make business plan and calculate the selling price of the business by the way the participants were given the task of group making business plan and individual tasks about calculating the selling price. Psychomotor aspect assessed to know entrepreneurship skill by way of participant do entrepreneurship in group according to simple business plan that have been made. The task of doing entrepreneurship was in the module. The success of the participants seen from the results of affective, cognitive and psychomotor assessment. The result of appraisal of affective aspect of entrepreneurship training participants on average was 86,7 with very good category. This shows that the average entrepreneurship entrepreneurship spirit was very good. The results of the cognitive aspect assessment of 83 participants with excellent category. This showed that the average ability to make business plan and calculate the selling price of entrepreneurship training participants was very good. The result of psychomotor assessment of participants was 90.2 with very good category. This indicates that the average ability to conduct entrepreneurial entrepreneurship efforts was very good. In line with Smith et al opinion that effective training develops skills and anticipates future needs [22].

\section{CONCLUSION}

Based on the analysis and discussion in the previous chapter, indicate that the training tools of life skill entrepreneurship based on syllabus, power point, and module by expert have fulfilled the category "valid" so that the device was suitable for use. The results showed that the percentage of training is $92 \%$ with very good category. The result of appraisal of affective aspect of entrepreneurship training participants on average is 86,7 with very good category. The results of the cognitive aspect assessment of 83 participants with excellent category. The result of psychomotor assessment of participants was 90.2 with very good category.

\section{REFERENCES}

[1] Cox, L.W., Mueller, S.L., Moss, S.E. The Impact of Entrepreneurship Education on Entrepreneurial Self-Efficacy // International Journal of Entrepreneurship Education..(2003) Vol. 1 (2). 
[2] [2] Petridou E., Sarri, K.. Developing "Potential Entrepreneurs" in Higher Education Institutes // Enterprising Culture. (2011) Vol. 19. Iss.79.

[3] [3] Chepurenko, A. (2013). Education reform: How to teach the higher education institutions to business. Retrieved from// URL: http://www.hse.ru/news/1163611/75135973.html Kazakhstan in 2011 / the Statistical year-book / (2012), Kazakhstan Agency ofStatistics Astana, 496.

[4] [4] Jose C. Sanchez. University training for entrepreneurial competencies: Its impact on intention of venture creation // International Entrepreneurship and Management Journal. (2011) Vol. 7.Issue 2: 239-254.

[5] [5] Liguori, E.W., Winkel, D., and Vanevenhoven, J. (2011). The impact of entrepreneurship education: Introducing the Entrepreneurial Education Project // Proceedings of the $2^{\text {nd }}$ Annual ICSB Research and Policy Conference. Washington DC

[6] [6] R. El Brashi Social entrepreneurship theory and sustainable social impact Social Responsibility Journal, 9 (2) (2013), pp. 188-209

[7] [7] H. Haugh, P. Tracey. 2004. The role of social enterprise in regional development Cambridge-MIT Institute (Ed.), Social enterprise and regional development conference, University of Cambridge, UK (2004) (Cambridge: Cambridge-MIT Institute)

[8] [8] J. Mair, E. Noboa. Social entrepreneurship: How intentions to create a social venture are formed J. Mair, J. Robinson, K. Hockers (Eds.), Social entrepreneurship, Palgrave Macmillan, New York, NY (2006), pp. 121-135CrossRefView Record in Scopus

[9] [9] A. Nicholl. 2006. Social entrepreneurship, new models of sustainable social change. University Press, Oxford (2006)

[10] [10] Lee L., Wong P.K. (2005). Entrepreneurship Education - A Compendium of Related Issues, Retrieved From http://papers.ssrn.com/sol3/papers.cfm?abstract_id=856227

[11] [11] Poerwati dan Amri. 2013. Kurikulum 2013. Surabaya.
[12] [12] B. Askun, N. Yildirim Insights on entrepreneurship education in public universities, in Turkey: Creating entrepreneurs or not?Procedia-Social and Behavioral Sciencies, 24 (2011), pp. 663676ArticleDownload PDF View Record in Scopus

[13] [13] D.J. Simon Sistematizando experiencias sobre educación en emprendimiento en escuelas de nivel Primaria Revista Mexicana de Investigación Educativa, 18 (56) (2013), pp. 159-190View Record in $\underline{\text { Scopus }}$

[14] [14] Thurik, S. Wennekers Points of view entrepreneurship, small business and economic growth Journal of Small Business and Enterprise Development, 11 (1) (2004), pp. 140-149 Cross Ref View Record in Scopus

[15] [15] Suhadi. 2007. Penyusunan Perangkat Pembelajaran dalam Kegiatan Lesson Studi. Di akses 15 Februari 2015.

[16] [16] Sanjaya W. 2012. Perencanaan dan Desain sistem Pembelajaran. Jakarta:Kencana, Prenada Media Group.

[17] [17] Djamarah dan Zain. 2006. Strategi Belajar Mengajar. Rineka Cipta: Jakarta

[18] [18] Amri S. 2013. Pengembangan dan Model Pembelajaran dalam Kurikulum 2013. Jakarta: Prestasi Pustaka.

[19] [19] Sudjana. 2009. Metode Statistika. Bandung: Tarsito.

[20] [20] Arifin, Z. 2014. Evaluasi Pembelajaran. Bandung: PT Remaja Roesdakarya.

[21] [21] Katerina K. Sarri, Ioannis L. Bakouros, Eugenia Petridou, "Entrepreneur training for creativity and innovation", Journal of European Industrial Training, (2010) Vol. 34 Issue: 3, pp.270-288, https://doi.org/10.1108/03090591011031755

[22] [22] Smitt, Rebecca, Rohan Jayasuriya, Peter Caputi and David Hammer. International Journal of Training and Development, (2008) Vol. 12 (1).PP 1360-3736 